\title{
Bat assemblages in fragmented forest complexes near Rogów (central Poland)
}

\author{
Grzegorz Lesiński ${ }^{1}$, Jakub Gryz ${ }^{2}$, Aleksander Rachwald ${ }^{2}$, Dagny Krauze-Gryz ${ }^{3 *}$ \\ ${ }^{1}$ Warsaw University of Life Sciences - SGGW, Faculty of Animal Sciences, 8 Ciszewskiego Str. 02-787 Warsaw, Poland; ${ }^{2}$ Faculty of Forestry, \\ 159 Nowoursynowska Str. 02-776 Warsaw, Poland; ${ }^{3}$ Forest Research Institute, Sękocin Stary, Braci Leśnej Str. 05-090 Raszyn, Poland \\ *Tel. +48 22 5938145, e-mail: dagny.krauze@wl.sggw.pl
}

\begin{abstract}
Habitat fragmentation affects bat assemblages living in forests by changing species composition, species richness and population densities. The aim of this paper was to determine the structure of bat assemblages in fragmented forests of central Poland (Experimental Forest Station SGGW in Rogów) based on data concerning bat fauna of this area.

Our work is based on published as well as unpublished data collected between 2011-2017 and the two main methods employed during field work were: (1) evening and night bat netting, (2) detection of flying bats on transects or in points by using ultrasound detectors. 16 bat species were observed with the most common ones being serotine bat Eptesicus serotinus (Schreb.), common noctule Nyctalus noctula (Schreb.) and brown long-eared bat Plecotus auritus (L.). Less numerous in overall but frequently observed in some sites were the western barbastelle Barbastella barbastellus (Schreb.) and the Daubenton's bat Myotis daubentonii (Kuhl). The following species occurred rarely: greater mouse-eared bat Myotis myotis (Bork.), Natterer's bat M. nattereri (Kuhl), whiskered bat M. mystacinus (Kuhl), Brandt's bat M. brandtii (Evers.), northern bat Eptesicus nilssonii (Keys. \& Blas.) parti-coloured bat Vespertilio murinus L., lesser noctule Nyctalus leisleri (Kuhl), common pipistrelle Pipistrellus pipistrellus (Schreb.), Nathusius' pipistrelle P. nathusii (Keys. \& Blas.), soprano pipistrelle P. pygmaeus (Leach) and grey long-eared bat Plecotus austriacus (Fish.).

Fragmented forests of the study area did not differ significantly in terms of bat species composition from other fragmented forests of central Poland (Płońsk Plain) nor the large forest complexes of the Bolimowska and Kampinoska Forests. In this study area, however, bat assemblages were characterized by a lower relative abundance of the common noctule and a higher relative abundance of the serotine bat as compared to assemblages in other forests of central Poland.

In conclusion, the forest fragmentation near Rogów does not significantly affect bat richness and fertilized habitats are suitable for relatively large populations of species such as the western barbastelle and lesser noctule.
\end{abstract}

Keywords: Chiroptera, forest patches, habitat fragmentation, species richness, mist netting, ultrasound detector

\section{Introduction}

Habitat fragmentation significantly affects the diversity of animal assemblages. This is especially true of fauna groups bond with only one habitat type and showing low dispersibility, for example, the small non-flying vertebrates and invertebrates. Bats, owing to their high flying activity, are capable of travelling long distances that alleviates the effect of ecosystem fragmentation. Forests are important habitats for these mammals, and provide both a day-today refuge and a feeding site for most bat species (Le- siński 2006). Though bats are associated with various ecosystems (ecological landscapes), their assemblages may be impoverished if forest fragmentation becomes important. A declining species richness and population density were found with decreasing size of forest patches when investigating bats in 0.3 to $18.0 \mathrm{~km}^{2}$ forest patches in central Poland. Likewise, there was a reduction in the share of species more closely associated with forests, with a simultaneous increase in the abundance of eurytopic and mostly synanthropic ones (Lesiński et al. 2007). Nonetheless, research conducted in various regions of the world, and with different degree of

Received: 10.04.2018 r., peer reviewed: 31.05 .2018 r., accepted: 6.08 .2018 r. 
woodland fragmentation, brings about ambiguous results. Bats sometimes survive well under conditions of highly fragmented forests (Ethier, Fahrig 2011) but, generally, under conditions of an average degree of fragmentation (Estrada, Coates-Estrada 2002; Gorresen, Willig 2004), while species capable of flying fast and more easily penetrating open areas will show a higher tolerance (Law et al. 1999).

Our goal was to determine the structure of forest bat assemblages in the vicinity of Rogów, in central Poland. Forests are highly fragmented there, and in some places patches are isolated by extensive fields and settlements. We used and analysed data collected in the above area to complete a general characteristics of the local bat fauna.

\section{Study area and methods}

The land section examined comprised mostly forests managed by the Experimental Forest Station of the Warsaw University of Life Sciences at Rogów (Fig. 1). The section takes an approximate $230 \mathrm{~km}^{2}$ of forest-field mosaic, with forests covering nearly $17 \%$ of the total surface and embracing 13 forest complexes sized between 37 and 1000 ha. Scots pine Pinus sylvestris $\mathrm{L}$. is the major forest species, dominating on about half of the surface, while mixed deciduous-coniferous forest and fresh deciduous forest are the main forest site types (jointly $83 \%$ ).

Six study areas were selected, embracing the following forests complexes (Fig. 1):

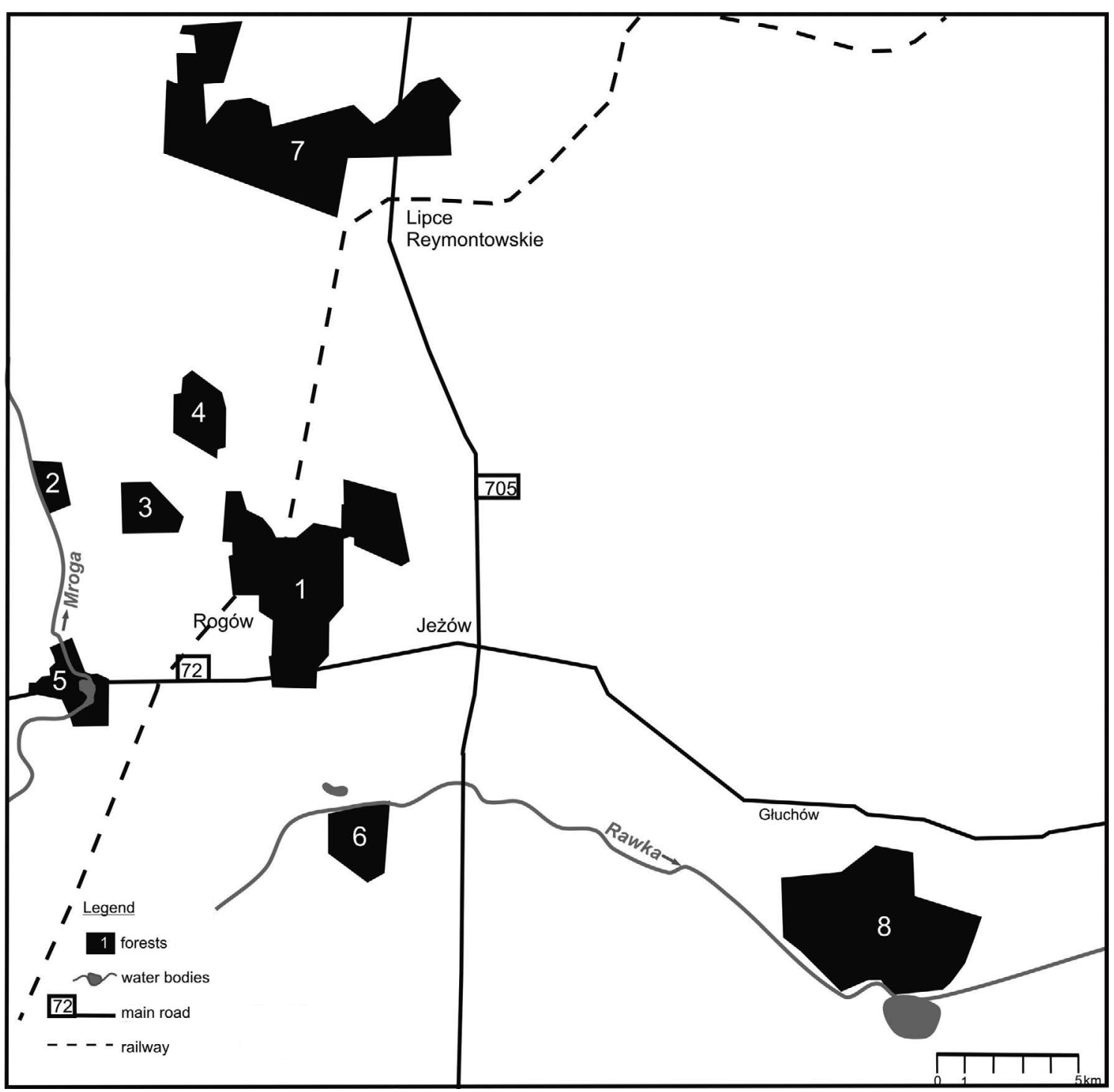

Figure 1. Distribution of forests in the study area: 1 - Central complex (Zimna Woda, Wilczy Dół, Doliska, Górki), 2 - Kołacin, 3 - Jasień, 4 - Zacywilki, 5 - Rogów, 6 - Popień, 7 - Lipce, 8 - Głuchów 
Area I - central complex of a surface of 950 ha.

Area II - Kołacin (70 ha), Jasień (140 ha) and Zacywilki (170 ha) forest complexes of a joint surface of 380 ha.

Area III - Rogów complex (170 ha), situated on the Mroga river.

Area IV - Popień, a small (170 ha) forest complex, at the sources of the Rawka river.

Area V - Lipce, a large (1000 ha) and most northerly situated forest complex.

Area VI - Głuchów, a large (1000 ha) forest complex with the south side adjacent to the Rawka river.

We used data on bats roosting within the above areas, both published (Gryz et al. 2011; Lesiński et al. 2014; Gryz et al., 2016a, b), and unpublished, collected in the years 2011-2017. Two basic methods were employed in the field, including: (1) evening and night bat trapping, using mist nets set mainly above forest tracks, and less frequently, above the mid-forest rivers, (2) bat registration along transects or at locations (points), using ultrasound detectors.

The six study locations (one above a river, five over forest tracks) were sampled in the years 2006-2009, while in the years 2014-2017 - seven study locations (all over the forest tracks). At each location, one to two nets were set, which fully blocked the bat migration routes. Upon capture, bat species and sex were recorded, and then, individuals were immediately released. Altogether, 139 individuals belonging to nine species were captured.

Investigations using ultrasound detectors consisted of registering the bat activity along linear transects from 2 to 3 km long (Judes 1989; Kowalski et al. 2000), and then analysing the recordings obtained (Osiejuk 2000). Where the latter was not possible, recordings at points were applied. The LunaBat multichannel ultrasound detector (DFR-1) and the BatSound 4.1 sound file analysis software were used (Pettersson Electronic AB, Uppsala, Sweden).

Ultrasound detectors were used in the research conducted in 2017. Three listening sessions (15 minutes) were performed at points and eight listening sessions (30 minutes) along transects in the respective areas: $\mathrm{I}-1$ transect and 2 points, $\mathrm{II}-1$ transect and 1 point and $\mathrm{VI}-3$ transects, where the research was carried out twice. Bats from the genus Myotis, were distinguished as a separate group, whereas the remaining bats that were not identified to species, were described as unidentified.

Other study methods were also used. Data concerning the bat roosting sites was collected less regularly (monitoring of crates and buildings in the summer and cellars during hibernation). 13 dead specimens were found on roads (Lesiński et al. 2009; Lesiński G., Gryz J. non-published data). The analysis of owl diet yielded five bats in the pellet material of tawny owl Strix aluco L. (of 5,020 vertebrates caught), and one bat in the food of long-eared owl Asio otus L. (of 3,030 vertebrates caught). In addition, information was collected from zoologists conducting research in the area as well as from interviews among the local population.

Differences in the shares of individual bat species among all the bats fauna recorded were compared using the $\mathrm{Chi}^{2}$ test (with Yates correction) in the $2 \times 2$ tables. The programme Statistica ver. 12 (Statsoft Inc. 2013) was used for calculations.

\section{Results}

A total of 16 bat species were recorded within the entire area under study. Trap record of bats in the respective selected study areas is given below:

\section{Area I}

Net trapping yielded seven bat species, including: Brandt's bat Myotis brandtii (Evers.), Daubenton's bat M. daubentonii (Kuhl), serotine bat Eptesicus serotinus (Schr.), lesser noctule Nyctalus leisleri (Kuhl), Nathusius' pipistrelle Pipistrellus nathusii (Keys. et. Blas.), brown long-eared bat Plecotus auritus (L.) and western barbastelle Barbastella barbastellus (Schreb.), with a distinct domination of serotine bat (Table 1). Moreover, one individual of particoloured bat Vespertilio murinus L. was captured for the museum's collection on July 29, 1950 (Gryz et al. 2011). With the use of mist net traps set around buildings and arboretum at Rogów, there were captured several individuals of brown long-eared bat. The presence of two species: serotine bat and common noctule Nyctalus noctula (Schreb.) was recorded using an ultrasound detector. In addition, a significant number of reports (up to 20\%) concerned non-species-identified bats from the genus Myotis (Table 2). Single individuals of brown long-eared bat and western barbastelle were found on the roads, killed by vehicles (Lesiński et al. 2009). In the vicinity of forest complexes, there were monitored house cellars identified as the winter roosting sites. On December 27, 2007, one individual of brown long-eared bat was reported from three facilities at Rogów, two at Przyłęk Duży, and one individual of grey long-eared bat Plecotus austriacus (Fisch.) at Gajówka Zimna Woda (Gryz et al. 2011). During the inspection of bat crates, one brown long-eared bat was found on July 15, 2007. Also, one individual of this species was recorded in the diet of tawny owl (June 16, 2009).

\section{Area II}

At the Jasien place, one cellar with a single roosting brown long-eared bat was found on 27.12.2007. In addition, serotine bat, common noctule, western barbastelle and Myotis sp. were registered with the use of ultrasound detector in a forest tract (Table 2). 


\section{Area III}

Bats were captured in the nets set on the Mroga river. Among the four species captured, including: whiskered bat Myotis mystacinus (Kuhl), Daubenton's bat, common noctule and lesser noctule $N$. leisleri (Kuhl), the most common were Daubenton's bats (Table 1). The presence of Daubentons's bat (three individuals), Nathusius' pipistrelle (one) and common noctule (five) was recorded during the monitoring of a road crosscutting the forest complex, in the years 2008-2009 (Lesiński et al. 2009). Single individuals of Daubenton's and serotine bats were also found during the monitoring of the same road, on June 30, 2011. In an oak hollow at the roadside, a roosting colony of common noctule was detected $6.5 \mathrm{~m}$ above the ground (registered based on voices heard during the day), on June 22, 2010. Dead specimens of the aforementioned bat species were also found on the road at the very place.

\section{Area IV}

Three bat species (Brandt's bat, serotine bat and brown long-eared bat) were captured in the nets set above the forest tracks (Table 1).

\section{Area V}

During two net trapping events, six bat species were identified, including: whiskered bat, serotine bat, common noctule, lesser noctule, brown long-eared bat and western barbastelle (Table 1). One individual of Natterer's bat Myotis nattereri (Kuhl) was determined in the diet of tawny owl, in the material collected on July 09, 2015 (Gryz, Krauze-Gryz 2016a).

\section{Area VI}

Within the entire study section, the only recording of greater mouse-eared bat M. myotis (Bork.) was made in this

Table 1. Mist netted bats in the study area in the years 2006-2017.

Source of data: P - Gryz et al. (2011), NP - unpublished data, D - mist netting over forest roads, $\mathrm{W}$ - mist netting at river bodies.

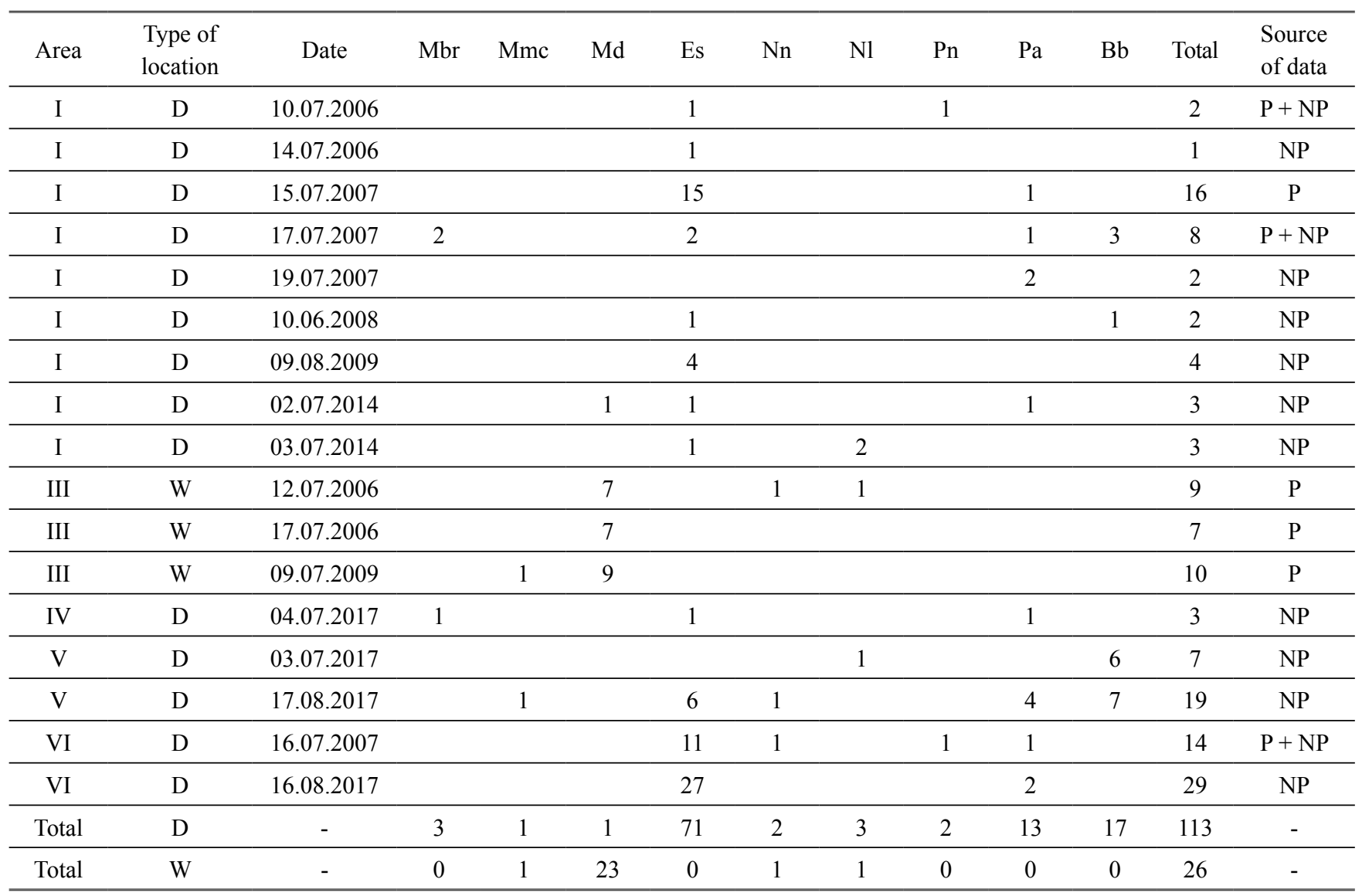

$\mathrm{Mbr}-$ Myotis brandtii, Mmc - M. mystacinus, $\mathrm{Md}-$ M. daubentonii, Es - Eptesicus serotinus, $\mathrm{Nn}-$ Nyctalus noctula, $\mathrm{Nl}-$ N. leisleri, Pn - Pipistrellus nathusii, $\mathrm{Pa}$ - Plecotus auritus, $\mathrm{Bb}$ - Barbastella barbastellus 
area (one male, found on August 22, 1966). In addition, single individuals, which arrived at the museum collection, involved: Brandt's bat noted on July 27, 1966, lesser noctule found on May 25, 1966 and soprano pipistrelle Pipistrellus pygmaeus (Leach) found on September 3, 1969 (Gryz et al. 2011). During the net trappings, the following four species were identified: serotine bat, common noctule, Nathusius' pipistrelle and brown long-eared bat (Table 1). Two bats were found in the owl pellet material: one individual of western barbastelle - in the tawny owl diet at the Lochów forest lodge, on July 03, 2017, and one common noctule - in the diet of long-eared owl, on April 13, 2012 (Lesiński et al. 2014). One dead specimen of serotine bat was found in the lodge attic, on July 2007 (Gryz et al. 2011). Many bat species were registered using an ultrasound detector. The sound screening enabled to identify the following species: serotine bat (dominant - almost $50 \%$ of recordings), common noctule, lesser noctule, western barbastelle, Myotis sp., common pipistrelle Pipistrellus pipistrellus (Schreb.), while northern bat Eptesicus nilssonii (Keys. et Blas.) was found solely within Area VI, and only when the above method was employed (Table 2).

16 bat species were noted within the entire study section, while the number of species in the respective areas fluctuated from three to 11 . Serotine bat was the most common species within all the study areas, followed by common noctule and brown long-eared bat (Table 3 ).

Nine species were net trapped, with serotine bat most often found over the roads, whereas western barbastelle and brown long-eared bat were less frequent. Daubenton's bat was most frequently encountered over the watercourses (Table 1). Likewise, serotine bat turned out to be the most frequently recorded when using the ultrasound detector, though common noctule and western barbastelle were also registered, as were the bats from the genus Myotis (Table 2).

\section{Discussion}

The forests under study did not differ in terms of the bat species number (16) from other forests in central Poland, both relatively fragmented - on the Płońsk Upland (14) (Lesiński et al. 2006, Lesiński 2009), and less fragmented as Bolimów Forest (14) (Lesiński, Janus 2017; Lesiński et al. 2018) and Kampinos Forest (15) (Kowalski, Lesiński 1995; Lesiński 2003). When comparing the species dominance structure between these forests, it was found that the share of Natterer's and brown long-eared bats in the bat assemblage captured over the roads in the vicinity of Rogów was lower, and that of serotine bat higher, than in the aforementioned forest aeras. Serotine bat belongs to the strongly eurytopic species, which are tolerant of a high forest fragmentation
Table 2. Bats registered with the aid of ultrasound bat detector in the three study areas. The number of registered flights and percentages of each species and unidentified individuals were given. Myotis spp. group contains all registered individuals from the genus, not identified to species level.

\begin{tabular}{lrrrrrr}
\hline \multirow{2}{*}{ Species } & \multicolumn{2}{c}{$\mathrm{I}$} & \multicolumn{2}{c}{ II } & \multicolumn{2}{c}{ VI } \\
\cline { 2 - 8 } & $\mathrm{N}$ & $\%$ & $\mathrm{~N}$ & $\%$ & $\mathrm{~N}$ & $\%$ \\
\hline Eptesicus serotinus & 8 & 11 & 24 & 44 & 66 & 47 \\
\hline Nyctalus noctula & 25 & 35 & 11 & 20 & 19 & 14 \\
\hline Myotis spp. & 14 & 20 & 3 & 6 & 20 & 14 \\
\hline Barbastella barbastellus & 22 & 31 & 8 & 15 & 1 & 1 \\
\hline Nyctalus leisleri & 0 & 0 & 0 & 0 & 5 & 4 \\
\hline Pipistrellus pipistrellus & 0 & 0 & 0 & 0 & 4 & 3 \\
\hline Eptesicus nilssonii & 0 & 0 & 0 & 0 & 2 & 1 \\
\hline Indet. & 2 & 3 & 8 & 15 & 23 & 16 \\
\hline Total & 71 & 100 & 54 & 100 & 140 & 100 \\
\hline
\end{tabular}

Table 3. Bat species registered in the study areas

\begin{tabular}{|c|c|c|c|c|c|c|}
\hline Species & I & II & III & IV & V & VI \\
\hline Myotis myotis & & & & & & + \\
\hline M. nattereri & & & & & + & \\
\hline M. mystacinus & & & + & & + & \\
\hline M. brandtii & + & & & + & & + \\
\hline M. daubentonii & + & & + & & & \\
\hline Vespertilio murinus & + & & & & & \\
\hline Eptesicus serotinus & + & + & + & + & + & + \\
\hline E. nilssonii & & & & & & + \\
\hline Nyctalus leisleri & + & & + & & + & + \\
\hline N. noctula & + & + & + & & + & + \\
\hline Pipistrellus pipistrellus & & & & & & + \\
\hline P. pygmaeus & & & & & & + \\
\hline P. nathusii & + & & + & & & + \\
\hline Plecotus auritus & + & + & & + & + & + \\
\hline P. austriacus & + & & & & & \\
\hline Barbastella barbastellus & + & + & & & + & + \\
\hline Total & 10 & 4 & 6 & 3 & 7 & 11 \\
\hline
\end{tabular}

(Lesiński et al. 2007). The share of species with lower tolerance to forest fragmentation, such as lesser noctule and western barbastelle (Lesiński et al. 2007), did not differ significantly from those found in the other forest tracts (Table 4). 
Table 4. Comparison of species structure (\%) of bats mist netted over forest roads in the study area and in forests of Płońsk Upland (Lesiński et al. 2006), Bolimowska Forest (Lesiński et al. 2018) and Kampinos Forest (Lesiński et al. 2011).

Sample size is given $(\mathrm{N})$. Shares that were statistically significant from those reported for Rogów are shown in bold, Chi ${ }^{2}$ and $\mathrm{p}$ values are given in brackets.

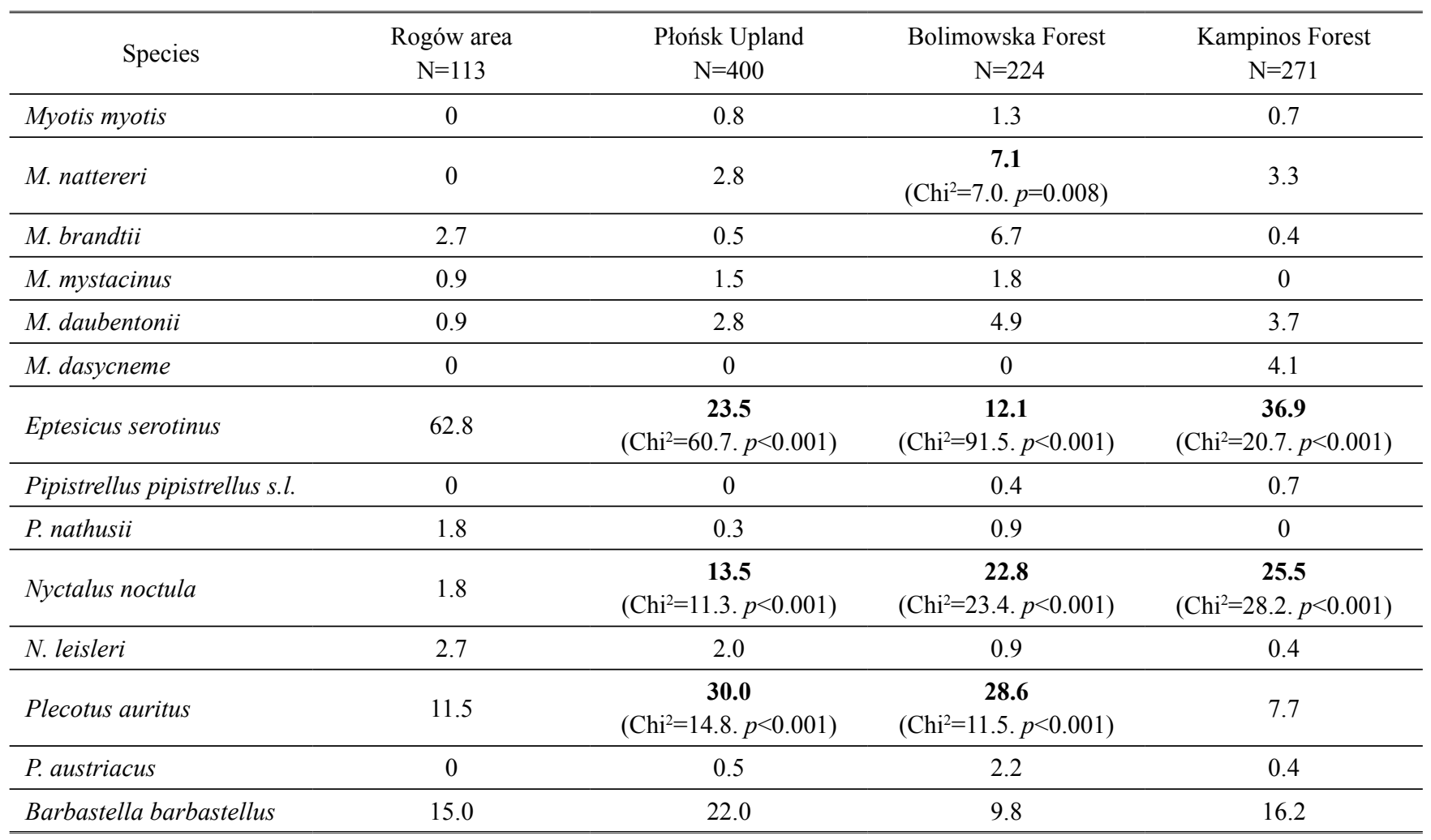

Only when the area of forest tracts was lower than $1 \mathrm{~km}^{2}$, a considerable decline in the number of species and relative density of bat assemblages were noted in the forests of the Płońsk Upland (Lesiński et al. 2007), and there were very few such forests in the vicinity of Rogów. De Jong (1995) in Sweden found weaker association between the number of bat species and the size of forest patches than between the bat numbers and the habitat type.

Bechstein's bat Myotis bechsteinii (Kuhl) was not found in the bat assemblages within the study area, though it was noted from the areas distanced only a few dozen kilometres to the south and east (Fuszara, Cygan 1994; Kowalski et al. 1996; Domański 2003; Sachanowicz et al. 2006; Ciechanowski 2018), and even to the north, where a single swarming site was described (Fuszara, Kowalski 2009). According to estimates by Sachanowicz and others (2006), 15-16 species of bats occur in this part of Poland. It can be assumed that almost all potentially identifiable species were found in the vicinity of Rogów. The presence of pond bat Myotis dasycneme (Boie) is not to be excluded, neither can be the presence of Bechstein's bat or Kuhl's pipistrelle
Pipistrellus kuhlii (Kuhl), which was noted in Warsaw, and recently shows an expanding trend (Popczyk et al. 2008).

Data obtained from detector recordings highlight the frequent presence of bats typical of forests in one of the locations (Area I), and the dominance of eurytopic species in others (Areas II and VI). In the Area I, the co-domination was found of western barbastelle, a strictly forest species associated with structurally rich stands with a large share of deciduous species (Dietz et al. 2009; Hillen et al. 2009; Gottfried et al. 2015) with common noctule, which is a forest and park species and hunts in open spaces (Rachwald 1992), and with bats from the genus Myotis. In the other two areas, there predominated serotine bat - a synanthropic species with a broad spectrum of foraging grounds (Lesiński et al. 2000; Dietz et al. 2009). On the other hand, serotine bat in Area I proved to be relatively rare (Table 2). Area I embraces a large forest complex, while forests in Area II are highly fragmented, which explains the above outcome. However, differences in bat species composition between Areas I and VI may result from differences in the stand structure and composition. It is also worth mentioning that serotine bat dominated in the net capture in Area VI as well (Table 1). 
Common pipistrelle and northern bat were found in the study area only with the aid of an ultrasound detector. Six bat species were registered using this method. The remote sensing methods, to which the above method belongs, do not allow for identifying species with a far-reaching certainty for all bat flights registered. There is always some percentage of completely unidentified signals, even under most favourable conditions, as well as a number of animals classified only to the genus or a group of genera. This applies most frequently to bats from the genus Myotis, as well as (to a lesser extent) to the genera Nyctalus, Vespertilio and Eptesicus. Northern bat Eptesicus nilssonii (Keys. et Blas.) belongs to species rarely listed in central Poland (Hejduk et al. 2001; Lesiński et al. 2008), while its presence and reproduction in the forests near Rogów may by confirmed by the recording of individuals, for example, in the net capture or in the roosting sites. Bats were rarely recorded in the diet of owls in this area as they accounted for only $0.1 \%$ of vertebrate prey of tawny owl. This differs slightly from the results obtained in the nearby forests, including: Bolimów Forest $(0.6 \%-$ Lesiński et al. 2016), Kampinos Forest (0.6\% - Lesiński et al. 2013 ), Chojnowski Landscape Park (0.3\% among mammals - Romanowski et al. 2014) and Mazowiecki Landscape Park (0.3\% - Lesiński et al. 2016b).

Forest fragmentation in the area under study does not significantly compromise the bat species richness. The number of species (16) is high, and includes some bats threatened at a European scale, such as greater mouse-eared bat Myotis myotis (Bork.), lesser noctule and western barbastelle. However, the effects of forest environment fragmentation can be seen in the dominance structure of bat assemblages in view of the large presence of synanthropic and eurytopic species, including serotine bat and brown long-eared bat.

\section{Conflicts of interests}

The authors declare the lack of potential conflicts.

\section{Acknowledgment and source of funding}

The study was financed from the authors' own sources.

\section{References}

Ciechanowski M. 2018. Nocek Bechsteina Myotis bechsteinii, w: Atlas ssaków Polski (red. H. Okarma i in.). http://www.iop.krakow.pl/ssaki/Gatunek.aspx?spID=160 [9.04.2018].

Dietz C., von Helversen O., Nill D. 2009. Nietoperze Europy i Afryki Północno-Zachodniej. Biologia, rozpoznawanie, zagrożenia. Multico Oficyna Wydawnicza, Warszawa, 400 s. ISBN 978-83-7073-673-6.
Domański J. 2003. Nowe zimowe stanowisko nocka Bechsteina Myotis bechsteinii (Kuhl, 1817) w środkowej Polsce. Nietoperze 4: 172-173.

Estrada A., Coates-Estrada R. 2002. Bats in continuous forest, forest fragments and in an agricultural mosaic habitat-island at Los Tuxtlas, Mexico. Biological Conservation 103: 237-245. DOI 10.1016/S0006-3207(01)00135-5.

Ethier K., Fahrig L. 2011. Positive effects of forest fragmentation, independent of forest amount, on bat abundance in eastern Ontario, Canada. Landscape Ecology 26: 865-876. DOI 10.1007/ s10980-011-9614-2.

Fuszara M., Cygan J. P. 1994. Nowe stanowisko nocka Bechsteina, Myotis bechsteini (Kuhl, 1818) w centralnej Polsce. Przegląd Zoologiczny 38: 335-337.

Fuszara M., Kowalski M. 2009. Nocek Bechsteina Myotis bechsteinii (Kuhl, 1817) podczas jesiennego rojenia w fortach modlińskich. Nietoperze 10: 81-83.

Gorresen P. M., Willig M. R. 2004. Landscape responses of bats to habitat fragmentation in Atlantic forest of Paraguay. Journal of Mammalogy 85: 688-697. DOI 10.1644/BWG-125.

Gottfried I., Gottfried T., Fuszara E., Fuszara M., Ignaczak M., Jaros R., Piskorski M. 2015. Breeding sites of the barbastelle Barbastella barbastellus (Schreber, 1774) in Poland. North -western Journal of Zoology 11: 194-203.

Gryz J., Krauze-Gryz D. 2016a. Kręgowce w pokarmie puszczyka Strix aluco na terenie kompleksu leśnego Lipce (Nadleśnictwo Rogów). Parki Narodowe i Rezerwaty Przyrody 35(3): 89-96.

Gryz J., Krauze-Gryz D. 2016b. Wpływ pory roku i dostępności gryzoni leśnych na skład pokarmu puszczyka Strix aluco w warunkach mozaiki polno-leśnej środkowej Polski. Sylwan 160(1): 57-63.

Gryz J., Krauze-Gryz D., Lesiński G. 2011. Mammals in the vicinity of Rogów (central Poland). Fragmenta Faunistica 54: 183-197.

Hejduk J., Stopczyński M., Pawenta W. 2001. Nietoperze okolic Łodzi. Łódzka Grupa Chiropterologiczna, Łódź, 1-40.

Hillen J., Kiefer A., Elle O., Veith M. 2009. Foraging site fidelity shapes the spatial organisation of a population of female western barbastelle bats. Biological Conservation 142: 817-823. DOI 10.1016/j.biocon.2008.12.017.

de Jong J. 1995. Habitat use and species richness of bats in a patchy landscape. Acta Theriologica 40: 237-248.

Judes U. 1989. Analysis of the distribution of flying bats along line -transects, w: European bat research (red. V. Hanák, I. Horáček, J. Gaisler). Charles University Press, Praha, Czech Republic, 311-318.

Kowalski M., Krasnodębski I., Sachanowicz K., Dróżdż R., Wojtowicz B. 1996. Skład gatunkowy, wybiórczość kryjówek i miejsc żerowania nietoperzy w Puszczy Kozienickiej. Kulon 1: 25-41.

Kowalski M., Lesiński G. 1995. Skład gatunkowy i wybiórczość kryjówek nietoperzy w Puszczy Kampinoskiej. Przegląd Przyrodniczy 6(2): 99-108.

Kowalski M., Rachwald A., Szkudlarek R. 2000. Standard prac detektorowych. Nietoperze 1: 93-96.

Law B. S., Anderson J., Chidel M. 1999. Bat communities in a fragmented forest landscape on the south-west slopes of New South Wales, Australia. Biological Conservation 88: 333-345. DOI 0.1016/S0006-3207(98)00118-9. 
Lesiński G. 2003. Nietoperze, w: Kampinoski Park Narodowy (red. R. Andrzejewski), Kampinoski Park Narodowy, Izabelin, t. I: 647-654. ISBN 83-88823-93-0.

Lesiński G. 2006. Wpływ antropogenicznych przekształceń krajobrazu na strukturę i funkcjonowanie zespołów nietoperzy w Polsce. Wydaw. SGGW, Warszawa, 211 s. ISBN 83-7244-733-0.

Lesiński G. 2009. Stanowiska nietoperzy (Chiroptera) na Mazowszu i Podlasiu wykryte w wyniku analizy zrzutek puszczyka Strix aluco. Nietoperze 10: 55-63.

Lesiński G., Fuszara E., Fuszara M., Popczyk B., Ruprecht A. L. 2008. The occurrence of the northern bat Eptesicus nilssonii (Keyserling et Blasius, 1839) in Warsaw and its vicinity, Central Poland. Nyctalus (N.F.) 13: 137-141.

Lesiński G., Fuszara E., Kowalski M. 2000. Foraging areas and relative density of bats (Chiroptera) in differently human-transformed landscapes. Zietschrift für Säugetierkunde 65: 129-137.

Lesiński G., Gryz J., Krauze D. 2009. Nietoperze ginące na drodze w okolicy Rogowa (województwo łódzkie). Nietoperze 10: 70-72.

Lesiński G., Gryz J., Krauze-Gryz D. 2014. Borowiec wielki Nyctalus noctula jako ofiara uszatki Asio otus. Nietoperze 13: 39-40.

Lesiński G., Gulatowska J., Kowalski M., Fuszara E., Fuszara M., Wojtowicz B. 2006. Nietoperze Wysoczyzny Płońskiej. Nietoperze 7: 39-55.

Lesiński G., Hejduk J., Gajęcka K., Górecki M. T., Janus K., Zieleniak A. 2018. Nietoperze Chiroptera Bolimowskiego Parku Krajobrazowego i terenów przyległych. Parki Narodowe i Rezerwaty Przyrody 37: 65-80.

Lesiński G., Janus K. 2017. Nietoperze Bolimowskiego Parku Krajobrazowego i okolic. Wydaw. Zespół Parków Krajobrazowych Województwa Łódzkiego, Łódź. ISBN 978-83-64899-70-6.

Lesiński G., Janus K., Nowak K., Pruszkowska A. 2016a. Drobne ssaki Bolimowskiego Parku Krajobrazowego i okolic na podstawie analizy diety puszczyka Strix aluco. Parki Narodowe i Rezerwaty Przyrody 35(4): 57-69.

Lesiński G., Kowalski M., Wojtowicz B., Gulatowska J., Lisowska A. 2007. Bats on forest islands of different size in an agricultural landscape. Folia Zoologica 56: 153-161.
Lesiński G., Olszewski A., Popczyk B. 2011. Forest roads used by commuting and foraging bats in edge and interior zones. Polish Journal of Ecology 59: 611-616.

Lesiński G., Romanowski J., Gryz J., Olszewski A., Kowalski M., Krauze-Gryz D., Olech B., Pepłowska-Marczak D., Tarłowski A. 2013. Small mammals of Kampinos National Park and its protection zone, as revealed by analyses of the diet of tawny owls Strix aluco. Fragmenta Faunistica 56: 65-81.

Lesiński G., Stolarz P., Dąbrowski R., Gryz J., Krauze-Gryz D., Skrzypiec-Nowak P., Świć J. 2016b. Small mammals in the diet of owls in the Masovian Landscape Park and its adjacent areas. Fragmenta Faunistica 59: 73-86.

Osiejuk T. 2000. Metody nagrywania i analizy dźwięku w badaniach bioakustycznych. Nietoperze 1: 71-91.

Popczyk B., Lesiński G., Baumann A., Wojtowicz B. 2008. Kuhl's pipistrelle, Pipistrellus kuhlii (Kuhl, 1817) or Pipistrellus lepidus Blyth, 1845, in Central Poland - accidental record or a result of expansion? Nyctalus (N.F.) 13: 279-281.

Rachwald A. 1992. Habitat preference and activity of the noctule bat Nyctalus noctula in the Białowieża Primeval Forest. Acta Theriologica 37: 413-422.

Romanowski J., Tarłowski A., Lesiński G., Olszewski A. 2014. Drobne ssaki Chojnowskiego Parku Krajobrazowego w pokarmie puszczyka Strix aluco. Chrońmy Przyrodę Ojczysta 70: 63-67.

Sachanowicz K., Ciechanowski M., Piksa K. 2006. Distribution patterns, species richness and status of bats in Poland. Vespertilio 9-10: 151-173.

Statsoft Inc. 2013. Statistica for Windows [Computer program manual]. Tulsa, Oklahoma United States, Statsoft Inc.

\section{Authors' contribution}

G.L. - field work, statistical analysis, writing; J.G. - conceptualisation, field work, data analysis, writing; A.R. - analysis of collected materials, writing; D.K-G - field work, writing. 